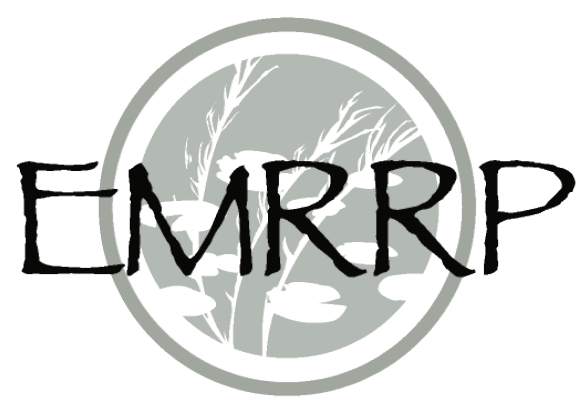

\title{
Marsh Assessment and Restoration Implementation at Three Salt Marshes in Response to Relative Sea Level Rise: A Report from Webinars and Supplemental Findings
}

by Christine M. VanZomeren ${ }^{1}$, Elizabeth O. Murray², and Damarys Acevedo-Mackey ${ }^{3}$

PURPOSE: The following technical note (TN) provides a summary of marsh assessment, design, implementation, and monitoring at three salt marsh restoration projects undertaken to address the effects of relative sea level rise (RSLR). This TN synthesizes the findings from a 2016 summer webinar series and also incorporates supplemental information on restoration implementation.

BACKGROUND: Recent research has focused on how salt marshes manifest symptoms of distress due to RSLR, how to properly diagnose stressors associated with observed salt marsh degradation, how to identify appropriate restoration techniques to address the specific causes of distress, and how to assess the immediate and long-term responses to restoration actions. A research work unit entitled Restoring and Sustaining Ecological Function in Coastal Marshes Affected by Sea Level Rise funded by the Ecological Management and Restoration Research Program (EMRRP) is currently investigating these topics. Ultimately, the work unit will develop a technical framework delineating the ecological and environmental considerations relevant to the restoration of existing, distressed salt marshes for the purpose of offsetting the effects of RSLR. The framework will make recommendations based on a synthesis of published literature and information from ongoing collaborations at three field demonstration projects, thereby, capturing existing information and identifying data gaps.

The three field case studies described in this TN span two coasts and vary in restoration goals, techniques, and monitoring protocols, providing a mechanism to evaluate the diverse strategies being employed across the nation (Figure 1). Each case study exhibited coastal marsh conditions stressed by RSLR. As a result, the study locations underwent restoration planning and implementation, and remain in post-implementation monitoring.

\footnotetext{
${ }^{1}$ Research Ecologist, U.S. Army Engineer Research and Development Center (ERDC), Environmental Laboratory (EL), Vicksburg, MS, (601) 634-3702, Christine.M.Vanzomeren@usace.army.mil

${ }^{2}$ Research Biologist, ERDC-EL, San Francisco, CA, (925) 212-1359, Elizabeth.O.Murray@usace.army.mil

${ }^{3}$ Research Civil Engineer, ERDC-EL, Vicksburg, Mississippi, (601) 634-4845, Damarys.Acevedo-Mackey@usace.army.mil
} 


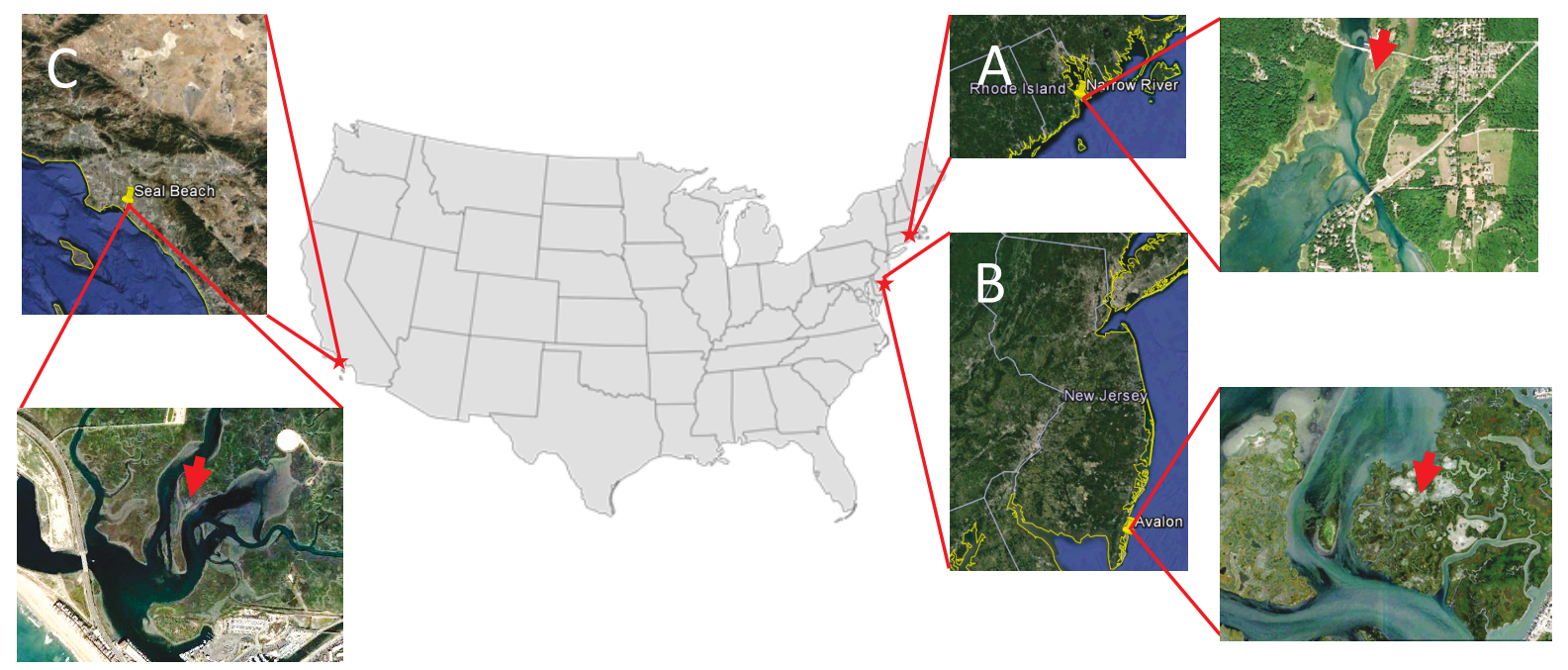

Figure 1. Geographic locations of salt marsh restoration case studies presented during this webinar series: (A) Narrow River Estuary, RI, (B) Avalon, NJ, and (C) Seal Beach, CA. Images obtained from Google Earth Pro.

The first case study occurs in the Narrow River Estuary, located within the John H. Chafee National Wildlife Refuge, Rhode Island (RI). The study location is managed by the U.S. Fish and Wildlife Service (USFWS) for conservation and management of fish and wildlife utilizing the refuge, including the vulnerable saltmarsh sparrow (Ammodramus caudacutus), which relies on high marsh at the study area for nesting. This study location was selected due to its habitat importance and the observed stressors (e.g., erosion and back-marsh ponding) affecting the area, thus, requiring multiple restoration techniques. The second case study focuses on a degrading marsh located to the west of Avalon, New Jersey (NJ), selected due to low elevation and buffering potential to the nearby coastal community. The third case study encompasses a coastal marsh located in the Seal Beach National Wildlife Refuge, Seal Beach, California (CA). The Seal Beach marsh supports one of the largest breeding populations of light-footed Ridgway's rail (Rallus longirostris levipes) in the United States. However, subsidence and interruption of local sediment supply by river channelization have resulted in extensive flooding and marsh elevations too low to provide natural nesting habitat. Seal Beach is the first known application of thin layer placement (TLP) in a west coast saltmarsh, broadening the geographic scope examined herein.

WEBINAR SERIES: A series of webinars detailing the progress of these three case studies was developed to foster communication to the salt marsh restoration community of practice. The webinar series addressed the following three phases of restoration process: (1) identifying at-risk marshes, (2) developing design criteria, and (3) project implementation. Utilizing the case studies described within, allowed comparisons to be made among approaches, concerns voiced, and initial results provided. Few published studies address restoration techniques dealing specifically with the threats of marshes to sea level rise, yet many marshes around the country appear to be at risk. As a result of this shortage in information, the webinar series attendance was diverse: 157 people from 56 entities - federal, state, and local agencies, consulting firms, and 
non-profit organizations - across 20 states, representing multiple disciplines, and spanning a wide range of geographic locations (Table 1).

The intent of the webinar series was to (1) share information on salt marsh restoration projects utilizing a variety of restoration techniques to address impacts of RSLR, (2) inform the science of salt marsh restoration in response to sea level rise, and (3) foster communication across disciplines, agencies, and geographic locations. The webinar series focused on specific restoration challenges associated with salt marshes experiencing RSLR, and the steps associated with planning and implementing the restoration effort. The descriptions provided in the following sections synthesize the information presented from the case studies during each webinar, and also includes additional information derived from questions raised during the webinar discussions.

\begin{tabular}{|c|c|c|c|c|c|}
\hline Group Name & No. & Type $^{1}$ & Group Name & No. & Type $^{1}$ \\
\hline Anchor QEA & 9 & C & $\begin{array}{l}\text { Pacific Northwest National Lab, Marine } \\
\text { Sciences }\end{array}$ & 1 & FA \\
\hline Bonneville Power Administration & 1 & FA & Point Blue Conservation Science CA & 1 & $\mathrm{NP}$ \\
\hline California Coastal Commission & 1 & SA & $\begin{array}{l}\text { San Francisco Bay Conservation and } \\
\text { Development Commission }\end{array}$ & 4 & SA \\
\hline California Dept. of Fish and Wildlife & 1 & SA & San Francisco Estuary Institute & 3 & NP \\
\hline California State Coastal Conservancy & 5 & SA & San Mateo County & 3 & LA \\
\hline $\begin{array}{l}\text { California State Water Resources } \\
\text { Control Board }\end{array}$ & 1 & SA & The Nature Conservancy & 2 & NP \\
\hline $\begin{array}{l}\text { California State Water Resources } \\
\text { Control Board }\end{array}$ & 1 & SA & United States Fish and Wildlife Service & 15 & FA \\
\hline $\begin{array}{l}\text { Chesapeake Bay National Estuarine } \\
\text { Research Reserve }\end{array}$ & 1 & FA & United States Geologic Survey & 2 & FA \\
\hline $\begin{array}{l}\text { Chesapeake Bay Sentinel Site } \\
\text { Cooperative }\end{array}$ & 1 & FA & United States National Park Service & 1 & FA \\
\hline $\begin{array}{l}\text { Delaware Dept. of Natural Resources } \\
\text { and Environmental Control }\end{array}$ & 1 & SA & University of California, Los Angeles & 1 & A \\
\hline $\begin{array}{l}\text { Elkhorn Slough National Estuarine } \\
\text { Research Reserve }\end{array}$ & 2 & FA & $\begin{array}{l}\text { United States Army Corps of Engineers } \\
\text { (USACE) Districts }{ }^{2}\end{array}$ & 58 & FA \\
\hline GreenVest & 1 & C & USACE Divisions $^{3}$ & 6 & FA \\
\hline Haley Aldrich & 1 & C & $\begin{array}{l}\text { USACE Engineer Research and } \\
\text { Development Center (ERDC) }\end{array}$ & 14 & FA \\
\hline HDR, Inc. & 1 & $\mathrm{C}$ & USACE Headquarters & 4 & FA \\
\hline Maryland Dept. of Natural Resources & 1 & SA & USACE Institute for Water Resources (IWR) & 3 & FA \\
\hline $\begin{array}{l}\text { New Jersey Dept. of Environmental } \\
\text { Protection }\end{array}$ & 1 & SA & $\begin{array}{l}\text { United States Environmental Protection } \\
\text { Agency }\end{array}$ & 7 & FA \\
\hline $\begin{array}{l}\text { National Oceanic and Atmospheric } \\
\text { Administration }\end{array}$ & 2 & FA & Wildfyre Group & 1 & C \\
\hline \multicolumn{6}{|l|}{ Total Participants: 157} \\
\hline \multicolumn{6}{|c|}{$\begin{array}{ll}1 & \text { Types of groups in attendance: Federal Agencies (FA), State Agencies (SA), Local Agencies (LA), Corporate (C), Non-profit } \\
& \\
& \text { (NP), Academic (A) } \\
\text { USACE Districts in attendance included Albuquerque, Baltimore, Galveston, Jacksonville, Little Rock, Los Angeles, Mobile, New } & \\
\text { England, New Orleans, New York, Norfolk, Pacific Ocean, Philadelphia, Rock Island, Sacramento, San Francisco, Savannah, } \\
\text { Seattle, and St. Louis. } \\
\text { USACE Divisions in attendance included Mississippi Valley, North Atlantic, South Atlantic, and Southwestern. }\end{array}$} \\
\hline
\end{tabular}

Indicators, metrics, and measurements for determining if salt marshes are at risk due to relative sea level rise. The first webinar, entitled How to determine if a salt marsh is at risk due to sea level rise: Indicators, metrics, and measurements, addressed the topic of assessing 
salt marsh condition. All three case study teams first identified marsh stress through a variety of visual observations (Table 2) and followed with the application of metrics or measurements to assess the marsh condition (Table 3 ).

The indicators of salt marsh distress vary across the case studies, dependent in part on differences in ecology, stressors, and anthropogenic effects. Only one metric, unhealthy vegetation, was cited as an indicator of degrading marsh condition by all three studies. However, despite the fact that the three marshes exhibited different symptoms that might be attributed to RSLR, it is important to note that these indicators are based on project-level observations, and not selected from a consistent list of potential indicators. Thus, an indicator may not be cited for a particular case study, either because that indicator was not assessed or not occurring. For example, the Seal Beach team did not cite bank erosion or impounded water because cursory observations indicated these were not occurring, and therefore, not issues of concern to document. However, in retrospect, pool/panne expansion and loss of high marsh species may be occurring, they might not be as prevalent or compelling as stunted vegetation and complete inundation of the low marsh at high tide, which undermines nesting success of low marsh-dependent rails. Avalon and Narrow River exhibited multiple indicators in common. These similarities in the two East Coast studies likely stem from their similar ecology, stressors, and recent disturbance from Hurricane Sandy.

Once visual observations indicated that salt marsh deterioration was occurring, a combination of field and computer based metrics and tools were employed to assess and document the marsh condition (Table 3). Like the visual indicators of salt marsh distress, the metrics and measurements used to assess marsh health vary across case studies. These differences could be attributed to differences in ecology, location, stressors, anthropogenic effects, level of funding available, and the programmatic concerns of the lead agency. All three sites utilized aerial imagery, some form of hydrology assessment, and vegetation surveys. Beyond that, the metrics selected were tied closely to the indicators of marsh distress observed in Table 2. 
At Narrow River, which exhibited impounded water near the upland boundary, loss of high marsh species, and pool/panne expansion, the project team measured attributes of soils, land use, accretion rates and nekton usage to better understand the potential causes and impacts of the distress. At Avalon, surveys showing low elevations explained the frequent high tide flooding, distressed vegetation, and expansion of pools and pannes observed in the marsh. The expanding pools were of particular concern, since they were also correlated with low nekton usage, which was cited as an indicator of poor marsh health and used in the selection for restoration areas within the marsh. At Seal Beach, where vegetation stress is widespread across the entire marsh plain and there's a history of both oil and groundwater extraction in the area, extensive studies addressing elevation, accretion rate, and sediment budget were used in combination with regional subsidence rates to document the long term trend in marsh elevation and loss (Takekawa et al. 2013). These studies concluded that the marsh cannot keep pace with local RSLR rates and vegetation that was once high enough to serve as nesting habitat for rails would not likely return without intervention.

Marsh restoration techniques were identified for each case study based upon the apparent cause of marsh distress. Various restoration techniques (runnel creation, erosion control, and TLP) were used at the Narrow River Estuary study area since multiple stressors were identified, including erosion, impounded water, and low elevation. At Avalon and Seal Beach, low elevation was identified as the main marsh stressor and thin layer placement of dredged material was the primary restoration intervention. It is notable that while some approaches across the three case studies were similar, the drivers of restoration were not always the same. At Seal Beach, the need to restore marsh elevation for breeding rail habitat was identified first, and then dredged material was sought. At Avalon, the marsh was initially identified as an area where dredged material generated from routine dredging could be used beneficially to improve habitat and increase coastal resilience. The marsh provides habitat for multiple species and serves as a buffer for storm surge for nearby communities. At Narrow River and Seal Beach, the two National Wildlife Refuges, the primary driver of restoration was habitat maintenance for specific species. At Seal Beach, where surrounding land use does not allow for extensive landward migration of the marsh, maintaining the habitat in place was crucial to the restoration design.

Design criteria that lead to a restoration plan for distressed marshes. The second webinar, entitled How to develop design criteria that lead to a responsible action for a distressed marsh, addressed the topic of salt marsh restoration design. Design criteria were dependent on restoration goals and the restoration technique. Multiple restoration techniques were employed at the Narrow River Estuary, including runnel creation, bank erosion control, thin layer application of dredged material on existing marsh to raise the marsh plain, and application of a thicker layer of dredged material in mudflats adjacent to the existing marsh to expand the marsh plain. Only thin layer application of dredged material was utilized at Avalon and Seal Beach, though they were applied differently to address site-specific goals.

The design criteria considerations for thin layer application of dredged material are shown in Table 4. The Narrow River Estuary and Avalon teams set target elevations for dredged material application, Seal Beach targeted a specific sediment application thickness. Application of dredged material at the Narrow River Estuary was designed for target slopes, contour, filling of newly expanding pools, all while avoiding creeks and channels to maintain drainage. The team 
also attempted to control expansion of the invasive species Phragmites in the restoration area by using runnels to promote salt water tidal exchange into the back portions of the marsh, where Phragmites dominates the upland-marsh boundary. Drainage and avoidance of creeks and channels were also considered in the restoration design at Avalon, where dredged material placement was focused on filling expanding pools that were largely devoid of vegetation.

\begin{tabular}{|c|c|c|c|}
\hline Design Criteria & $\begin{array}{c}\text { Narrow } \\
\text { River }\end{array}$ & Avalon & $\begin{array}{c}\text { Seal } \\
\text { Beach }\end{array}$ \\
\hline Site Access & $\mathrm{X}$ & $\mathrm{X}$ & $\mathrm{X}$ \\
\hline Feasibility & $\mathrm{x}$ & $\mathrm{x}$ & $\mathrm{x}$ \\
\hline Target High Marsh Elevation & $x$ & $x$ & \\
\hline Thickness of Sediment & & & $\mathrm{X}$ \\
\hline Target Slope & $\mathrm{X}$ & & \\
\hline Contour and Drainage & $\mathrm{x}$ & $\mathrm{X}$ & \\
\hline Avoidance Creeks/Channels & $x$ & $x$ & \\
\hline Sediment Properties & $x$ & $x$ & $\mathrm{x}$ \\
\hline Sediment Containment & & $x$ & $x$ \\
\hline
\end{tabular}

Containment of hydraulically placed sediment was a component of the design process at Avalon and Seal Beach. At Avalon, coir logs were used for containment of slurry solids while allowing dewatering. Hay bales and geotextile fabric secured with rebar were used to provide containment at Seal Beach, and a 50 foot buffer zone was established between the hay bales and the primary marsh bank to keep sediment out of adjacent essential fish habitat (i.e., eelgrass beds). Application of dredged material at Seal Beach also spanned the creek channels, requiring extensive sediment control (small dams of hay bales and sandbags) where the creeks intersected the buffer boundary.

Site accessibility and construction feasibility were particularly important design phase considerations. Accessibility factors included the distance from the dredge location to the restoration area, water depth and draft of dredge and other waterside equipment, and boat access and on-site activity schedule limitations due to tidal cycles. Construction feasibility considerations included permitting requirements, site trafficability, and availability of dredged material with desired geotechnical characteristics.

Unconsolidated surface sediments may prevent foot traffic on the site for an extended period post-placement, and require use of different monitoring methods after construction than were used prior to construction. Elevation surveys to confirm placement depths and final surface elevation, required particular consideration at Seal Beach. Sediment/dredged material particle size, contaminant levels, and required volumes were considered for all the study areas.

Data from test plots were utilized at Seal Beach and Narrow River to inform details of the design. At Seal Beach, tolerance of vegetation to different burial depths was tested by mechanically shoveling material into box plots of varying heights in a portion of the existing marsh, the results of this experiment indicated that burials up to twelve inches could be tolerated by the dominant plant species in the application area. At Narrow River, sediment was placed both mechanically and hydraulically to assess corresponding consolidation of salt marsh root layer, no significant consolidation of the underlying soil was noted during the period of observation. The volume of the placed material changed significantly depending on the method of application, with the slurry first settling and then consolidating significantly, and the mechanically placed material consolidated to a much lesser degree. 
Based on review of each of the three case studies and lessons learned, additional factors were identified for consideration in the design of future projects, including dredging equipment limitations and potential equipment impacts to the marsh. Designs could also be informed and improved by drainage pathway mapping to improve sediment containment design, modeling tidal flow with local benchmarks to improve target elevations, more extensive sediment source sampling for grain size to better predict which portions of the dredge source material are most appropriate for the marsh, improved estimates of sediment volume, bulking factors based on sediment texture, sorting, dispersal, consolidation rates to inform placement design, and sediment chemical parameters such as iron sulfides that could affect soil chemistry and plant growth at a restoration site.

Implementation of restoration for distressed salt marshes. The final webinar, entitled Responsible actions for a distressed salt marsh due to sea level rise, addressed the phases of restoration plan execution, including permitting, restoration implementation and associated troubleshooting, and metrics to assess restoration success.

Permitting: The permitting process varied among the three sites due to differences in state regulations, proposed activities, and possible impacts to ecological and cultural resources. Review by multiple agencies was required as part of the permitting process for all three sites.

Historic and cultural resources were a concern in the restoration area at Narrow River Estuary and required working with the Narragansett Indian Tribe, the RI State Historic Preservation Office, and USFWS Cultural Resources, under Section 106 of the Historic Preservation Act. Erosion control and runnel excavation required permits through the RI Department of Environmental Management, RI Coastal Resources Management Council, and USACE. Dredging and placement of dredged material on the marsh required permits from RI Department of Environmental Management and USACE, with additional review by the Environmental Protection Agency and National Marine Fisheries Service.

Restoration at Avalon required NJ Coastal General Permit \#24 for habitat creation, restoration, enhancement, Clean Water Act Section 401 Water Quality Certificate, Coastal Zone Management Program Consistency Determination for thin layer application of dredged material to the marsh, and Acceptable Use Determination (AUD) for beneficial use of dredged material through the NJ Department of Environmental Protection.

The Seal Beach project required a USACE Nationwide Permit \#27 for wetland restoration, a Section 7 Endangered Species Act consultation, Regional Water Quality Board Section 401 certification, National Historic Preservation Act Section 106 compliance, California Coastal Commission consistency determination, and California State Lands Commission lease agreement.

Implementation: Material placement and containment proved to be one of the biggest challenges, requiring multiple adjustments during construction. At Seal Beach, dredged material was placed directly on the marsh by "rainbowing" a slurry of water and sediment from a twelve inch cutterhead suction dredge. The dredge slurry was passed through a two inch debris screen, and pumped through a pipeline to the study area. A Power Scow drafting 18 inches was used both for assembling the pipeline, and for housing a high-pressure turret used for broadcasting the 
slurry. A Marsh Master MM-1LX was used to move pipeline and transport hay bales and other sediment control materials across the area (USFWS 2017, 2018).

The turret was initially equipped with a nozzle that led to higher than anticipated impact force, causing more damage and soil compaction than expected. Two alternate nozzle shapes were engineered in the field, an elliptical-shaped nozzle, and a round nozzle retrofitted with a deflector. The elliptical-shaped nozzle created a favorable placement pattern and reduction in marsh surface impacts. The round nozzle, retrofitted with an upward deflection crescent pipe section installed at the end of the nozzle, created a large placement radius, but less range, requiring the nozzle to be moved more frequently (Figure 2). The team ultimately selected the elliptical nozzle to complete material placement at Seal Beach (USFWS 2017, 2018).

At Avalon, the discharge of a $12-14$ inch hydraulic pipeline dredge was

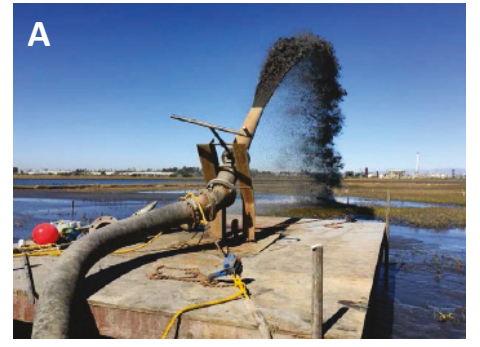

Figure 2. Spray patterns of $(A)$ oval nozzle, and $(B)$ round nozzle with a "spoon" curved deflection plate on the nozzle. (Curtain Maritime 2016). used to distribute material across the project area, a custom-made nozzle and spreader were connected at the end of the pipe for discharge into wider, shallower areas. A turret and nozzle were secured within a wooden structure on the marsh. ${ }^{1}$ A Marsh Master was used to install coir log containment prior to dredging operations and to on occasion to move the pipe during hydraulic placement. The discharge pipe had to be moved more frequently than anticipated, and placement operations were temporarily suspended in multiple instances to allow the slurried material to settle and dewater. Due to the resulting delays, the project could not be completed before the end of the dredging window, and material was placed on only a portion of the originally planned area.

At Narrow River, the material was dredged with a vertical dredge pump and placed in an upland area of the site, the material was then spread in the restoration area with a bulldozer using hand held real time kinematic (RTK) navigation to increase the accuracy of placement. This included the following two areas: the TLP on the existing marsh plain, and the thicker layer in adjacent mudflats. While sediment containment had been designed into the thick layer placement areas, in the form of floating booms and barriers separating these areas from the channel, no provision for material containment was made in the project design phase of the TLP on the marsh because it was to be mechanically placed after dewatering in upland. However, the dredged material was wetter than anticipated, and tended to flow beyond the boundaries of the intended placement areas. Within the placement area, fiber/coir logs and sections of pipe were added to contain the material. In addition, shell bags were used to prevent further erosion of existing marsh banks resulting from construction traffic and in high-wave areas.

\footnotetext{
${ }^{1}$ Piercy. C., T. Welp, D. Golden, M. Chasten, and J. Jahn. In Press. Wetland thin layer placement at Avalon, NJ.
} 
Monitoring: Many of the same metrics were used to assess the effects of material placement on the marsh (Table 5), as were used to assess marsh condition (Table 3), elevation and compaction, depth and duration of flooding, avifauna, invertebrate, and infauna species, vegetation community, and soil salinity. The monitoring metrics used for each case study varied, however, as a function of the level and source of funding, requirements of permits and partnering agencies, restoration goals, location, biology of the area, and possible stressors.

All three case studies monitored elevation/ compaction, vegetation community, and avifauna species, since all sites intended to raise marsh elevation and restore vegetation for a particular habitat or species. The similarities among the monitoring metrics utilized at Narrow River and Avalon could be attributed to their funding mechanism, since both locations used Hurricane Sandy Mitigation and Resilience Program funding for monitoring, this required use of The Salt Marsh Integrity Index developed by the USFWS for Atlantic marshes (Neckles et al. 2013; U.S. DoI 2015; Shriver et al. 2015). In contrast, several metrics were utilized at Seal Beach that are not required by the Salt Marsh Integrity Index (e.g., creek evolution and carbon sequestration).

Monitoring results are already offering insights that can improve future designs and goals. For instance, at Seal Beach a target placement thickness was set in the design goals and, on average, achieved across the site. However, placing sufficient material to achieve a target elevation was deemed a better goal for future projects, since the topographic relief and slurry flow resulted in low areas filling to greater depths than the design lift of 8-10 inches, while high portions of the marsh accumulated a thinner layer. In addition, consolidation of the applied material was greater than anticipated, though it tapered off after several months. ${ }^{1}$

Keeping sediment containment in place during storms and spring tides was an issue at both Seal Beach and at Avalon, requiring additional stabilization efforts partway through implementation. Perimeter coir logs (Avalon) and hay bales (Seal Beach) that washed away in storms or high tides were replaced, and where creeks intersected the project boundary at Seal Beach, multiple layers of hay bales were secured with rebar and sandbags. This appears to have delayed creek formation at Seal Beach, requiring gradual removal of the sediment control features to allow the newly consolidated material to be re-sculpted by the tides.

Another process was identified at Narrow River that may impact a site's restoration potential. In test plots, vegetation that had colonized in the first year died back in the second, and soil discoloration prompted the testing for and observation of iron sulfide. This prompted further

\footnotetext{
${ }^{1}$ Thorne, K. M., and C. M. Freeman. In Press. Thin-layer sediment application pilot project at Seal Beach National Wildlife Refuge: Elevation change analysis. Summary Report. Vallejo, CA: U. S. Geological Survey, Western Ecological Research Center.
} 
testing of the dredged material, and spurred iron sulfide testing at the other two sites to enable early identification of abnormal levels of iron sulfide production. While iron sulfide is present naturally in marshes, it can become problematic under certain conditions by causing temporary soil acidification. Monitoring continues at all of these sites, and the results of the adaptive management measures taken post-construction and additional soil tests will continue to be assessed and published over time.

DISCUSSION: As more marshes degrade due to stressors related to RSLR, and more restoration techniques are attempted to restore or sustain their function, communication of promising outcomes, challenges, lessons learned, and adaptations will inform the larger community of practice and promote success of future projects. The three projects and webinars synthesized in this TN offer examples of different restoration approaches. Flexibility is a requisite for success with such projects; troubleshooting was required during implementation for all three projects to secure positive outcomes and reduce unanticipated impacts.

All three of these sites are early in the monitoring period, and currently only offer a snapshot of early post-application development. However, monitoring continues at all three sites, and the results of that monitoring and any adaptive management will continue to inform the assessment of these restoration designs. As these are all test cases, documenting improvements in procedures learned during implementation, monitoring, and adaptive management, and disseminating that information to the restoration community of practice is critical to the refinement of these restoration techniques. The webinar series and this $\mathrm{TN}$ were intended to facilitate information sharing and to not only disseminate but glean information from the experiences of others that could be used to further refine assessment, characterization, design, implementation and monitoring methods of future projects. This study was part of a larger research effort focused on developing a systematic framework informing appropriate restoration measures to restore and sustain ecological function at coastal salt marshes affected by RSLR.

ADDITIONAL INFORMATION: Research presented in this TN was developed under the Environmental Management and Restoration Research Program (EMRPP). The USACE proponent for EMRPP is Ms. Mindy Simmons, the Program Manager is Dr. Trudy Estes, and the Technical Director is Dr. Al Cofrancesco. The webinar series was organized by Mr. John Childs. ${ }^{1}$ Links to the webinar series are provided in the reference section. Technical reviews provided by Dr. Jacob Berkowitz and Ms. Susan E. Bailey (ERDC Environmental Laboratory), Dr. Aubree Hershorin (SAJ), Mr. Larry Oliver (NAE), Ms. Metthea Yepsen (NJDEP), Ms. Jennifer White (USFWS), and Mr. Rick Nye (USFWS) are gratefully acknowledged.

The authors would also like to acknowledge collaboration of the lead agencies pertaining to each project for their contribution to this webinar series, and for providing supplemental data and reports for these projects. For additional information contact the authors (information provided on the first page), or contact the Program Manager of EMRRP, Dr. Trudy Estes (601-634-2125, Trudy.J.Estes@usace.army.mil).

\footnotetext{
${ }^{1}$ Formerly with the ERDC Environmental Laboratory, Currently with California Department of Department of Toxic Substances Control.
} 
This TN should be cited as follows:

VanZomeren, C. M., E. O. Murray, D. Acevedo-Mackey. 2019. Marsh Assessment and Restoration Implementation at Three Salt Marshes in Response to Relative Sea Level Rise: A Report from Webinars and Supplemental Findings. EMRRP Technical Notes Collection ERDC/TN EMRRP-EBA-23 Vicksburg, MS: U.S. Army Engineer Research and Development Center.

\section{REFERENCES:}

Neckles, H. A., J. E. Lyons, G. R. Guntenspergen, W. G. Shriver, and S. C. Adamowicz. 2015. Use of structured decision making to identify monitoring variables and management priorities for salt marsh ecosystems. Estuaries and Coasts 38:1215. doi:10.1007/s12237-014-9822-5.

Neckles, H. A., G. R. Guntenspergen, W. G. Shriver, N. P. Danz, W. A. Wiest, J. L. Nagel, and J. H. Olker. 2013. Identification of metrics to monitor salt marsh integrity on national wildlife refuges in relation to conservation and management objectives. Laurel, MD: Northeast Region. U.S. Geological Survey (USGS) Patuxent Wildlife Research Center.

Shriver, W. G., A. A. Wiest, S. C. Adamowicz, E. L. Tymkiw, K. A. Chadbourne, and E. King. 2015. Northeast regional protocol for the inventory and monitoring of salt marsh integrity. Hadley, MA: U. S. Fish and Wildlife Service (USFWS) Region 5.

Takekawa, J. Y., K. M. Thorne, K. J. Buffington, C. M. Freeman, and G. Block. 2013. Evaluation of subterranean subsidence at Seal Beach National Wildlife Refuge. Data Summary Report. Vallejo, CA: U. S. Geological Survey, Western Ecological Research Center. https://ecos.fws.gov/ServCat/DownloadFile/43709? Reference $=43162$.

U.S. Army Engineer Research and Development Center (ERDC). 2016. Ecological Function of Coastal Salt Marshes in Response to Sea Level Rise - Part 1. Accessed 31 March 2017. https://cwenvironment.erdc.dren.mil/learning.cfm? $\mathrm{CoP}=$ Restore.

U.S. Army Engineer Research and Development Center (ERDC). 2016. Ecological Function of Coastal Salt Marshes in Response to Sea Level Rise - Part 2. Accessed 31 March 2017. https://cwenvironment.erdc.dren.mil/learning.cfm? $\mathrm{CoP}=$ Restore.

U.S. Army Engineer Research and Development Center (ERDC). 2016. Ecological Function of Coastal Salt Marshes in Response to Sea Level Rise - Part 3. Accessed 31 March 2017. https://cwenvironment.erdc.dren.mil/learning.cfm? $\mathrm{CoP}=$ Restore.

U.S. Department of Interior (U.S. DoI). 2015. Recommendations for assessing the effects of the DOI Hurricane Sandy Mitigation and Resilience Program on ecological system and infrastructure resilience in the Northeast coastal region. Washington, DC: The Department of the Interior Metrics Expert Group. https://www.doi.gov/sites/doi.gov/files/migrated/news/upload/Hurricane-Sandy-project-metrics-report.pdf.

U.S. Fish and Wildlife Service (USFWS). 2017. Initiation of thin layer sediment augmentation on the Pacific coast. Agreement \# P14960110. San Diego, CA: U.S. Fish and Wildlife Service. https://www.fws.gov/uploadedFiles/P\%201496011\%2000\%20Oct-Dec\%202016\%20Quarterly\%20Report.pdf.

U.S. Fish and Wildlife Service (USFWS). 2018. Seal Beach Salt Marsh Sediment Augmentation Project. (Accessed 19 December 2018). https://www.fws.gov/refuge/seal beach/what we do/resource management/Sediment_Pilot Project.html.

NOTE: The contents of this technical note are not to be used for advertising, publication, or promotional purposes. Citation of trade names does not constitute an official endorsement or approval of the use of such products. 